\title{
Отбор статей российскими исследователями с помощью ресурса SCI-Hub
}

\begin{abstract}
На основе размещённых Дж. Боханнон и А. Элбакян в Интернете 28 млн отобранных с ресурса Sci-Hиb статей за период с 1 сентября 2015 по 29 февраля 2016 г. идентифицировано около 1,5 млн статей, отобранных российскими исследователями. Они были распределены по издательствам научной периодики, городам и регионам России, из которых происходил отбор статей. Например, среди 521 города России наибольшее количество статей было отобрано исследователями из Москвы (731,1 тыс. статей), Санкт-Петербурга (132,6), Новосибирска (57,5), Казани $(55,1)$ и Томска (26,4). Выполнены сравнения с аналогичными результатами украинских исследователей.
\end{abstract}

Ключевые слова: Sci-Hub, Elsevier, Springer, Дж. Боханнон, А. Элбакян, Россия, пиратская загрузка статей

DOI: $10.36535 / 0548-0019-2021-07-3$

\section{ВВЕДЕНИЕ}

После того как с сентября 2011 г. был запущен пиратский ресурс Sci-Hub, все публикации о нём носили больше эмоциональный и публицистический характер. Эта тематика вошла в научный дискурс после того, как Джон Боханнон и Александра Элбакян, основательница Sci-Hub, разместили данные по 28 млн запросов пользователей в Sci-Hub за период с 1 сентября 2015 г. по 29 февраля 2016 г. в открытом доступе [1]. Это позволило всем заинтересованным исследователям из многих стран мира анализировать использование Sci-Hub в своих странах и по отдельным областям научных исследований.

Джон Боханнон установил, что этим ресурсом пользуются научные работники не только из развивающихся и слаборазвитых стран, в которых затруднен доступ к подписным журналам, но и из развитых стран (четверть запросов идет из стран ОЭСР), которые имеют хороший доступ к подписным журналам [1] и не хотят жертвовать своим комфортом, получая к ним легальный доступ в своих научных библиотеках, что подтверждают опросы Жака Трависа [2]: «17\% респондентов заявили, что доступ к полным текстам через Sci-Hub был легче, чем через легальные каналы». Он установил также, что $37 \%$ респондентов не были в состоянии получить легальный доступ к нужным статьям, а 23\% выбрали Sci-Hub, так как они не согласны с ценовой политикой крупных коммерческих издателей научной периодики.

Всё это наилучшим образом охарактеризовал Симон Оксенхам, резюмируя своё интервью с Александрой Элбакян с броским заголовком "Встреча с Робин Гудом от науки” [3]: «Эффективность системы поражает. Она работает намного лучше, чем сравни- тельно примитивные способы доступа, предоставляемые исследователям в лучших университетах мира инструменты, за которые университеты должны раскошеливаться миллионами фунтов каждый год».

М. Паркилл [4] отобрал ТОР-100 статей из работы [1] в инструмент PlumX, и определил, что большинство из них было 2015 г. издания, т. е. пользователи Sci-Hub предпочитают получать самые свежие статьи. Причём большее число статей было посвящено физике, техническим наукам и наукам о жизни.

3. Бабуцидзе [5] изучил массивы отобранных статей экономической тематики [1] из ТОР-5 экономических журналов: «American Economic Review», «Quarterly Journal of Economics», «Journal of Political Economy», «Econometrica» и «Review of Economic Studies». Он отмечает небольшое количество статей из этих журналов, а запросы на них идут из слаборазвитых стран.

Г. Кабанас [6] по тем же данным обнаружил, что $36 \%$ всех статей доступно на открытой платформе Library Genesis (LibGen), работающей в паре с SciHub. Отмечено также, что $68 \%$ статей издательств Elsevier, Springer и Wiley имеются в LibGen. В то же время, в работе [7] приводится цифра $83 \%$ для статей этих же издательств.

Д. Химельштейн с соавторами [8] установили, что Sci-Hub обеспечивает бесплатный доступ к более чем $85 \%$ научных статей из подписных журналов, а также к 97\% статей издательства Elsevier, которое в связи с этим, как мы знаем, неоднократно выставляло судебные иски этому пиратскому ресурсу.

С. Назаровец [9] использовал данные работы [1] для получения распределения отобранных украинскими исследователями статей по издательствам и регионам, причём он выделил основные области знания, соответствующие этим статьям (на химию, фи- 
зику и астрономию пришлось 69\% статей, на медикофармацевтические науки - 13\%, на науки о жизни $12 \%$, на социальные науки - 6\%), а также наиболее часто встречаемые журналы («Journal of the American Chemical Society» - 6769 статей, «Organic Chemistry» 6038, «Physical Rev. B» - 4325, «Medicinal Chemistry» 3712 статей).

В работе [10] с использованием доступа University Association for Contemporary European Studies (UACES) к European Studies journals были отобраны журналы с IF $(\mathrm{WoS})>1$. Их анализ совместно с данными по отбору статей из работы [1] обнаружил, что читатели интересуются, в основном, проблематикой, связанной с популизмом, экстремизмом и экономическим кризисом.

По данным всё той же работы [1] Д. Андрочец [11] изучил публикации в области компьютерных наук, которых оказалось 5,95\% от общего количества публикаций и привел 20 самых востребованных статей. Первые пять стран, исследователи которых отбирали статьи по рассматриваемым наукам, выглядели так: Индия, Иран, Китай, США, Индонезия. Россия в этом ранжированном списке стояла на седьмом месте с 46659 статьями.

Б. Грешаке [12] показал, что из 62 млн статей отобранных пиратским образом через Sci-Hub $80 \%$ приходится на 9 издателей.

Итак, мы представили обзор публикаций (за исключением статьи [9]), за 2016-2017 гг., основанных на эмпирической базе работы [1]. Но, помимо статистического анализа отбираемых через Sci-Hub статей параллельно стали проводиться исследования по опросам пользователей этого пиратского ресурса. Отметим лишь работу [13], в которой описаны итоги широкомасштабного проекта Early career researchers (ECRs) по мотивациям использования Sci-Hub 106-ю молодыми исследователями из семи стран (Великобритания, Израиль, Испания, Китай, Малайзия, Польша, Франция). Эти исследователи опрашивались ежегодно в течение трёх лет. Было показано, что популярность Sci-Hub росла: в 2016 г этот ресурс использовали 6\% участников проекта, в 2018 г. - $25 \%$. Наибольшей популярностью он пользовался среди молодых исследователей во Франции. Было показано также, что в Китае Sci-Hub сильно блокируется, но в нём имеется свой пиратский ресурс 91lib.com. Даже если университетские библиотеки хорошо обеспечены подпиской на научную периодику, Sci-Hub используется предпочтительнее из-за удобства, по сравнению с лицензионным доступом через библиотеки. Отмечено, что сеть ResearchGate использовали $75 \%$ участников проекта.

Один из самых последних опросов исследователей и студентов об их зависимости от Sci-Hub был опубликован в начале января 2021 г. на сайте индийского репозитария блогов по интеллектуальной собственности и инновационной политики SpicyIP [14]. С 22 декабря 2020 по 2 января 2021 гг. опрошено 212 респондентов, из которых 140 (66\%) сильно зависят от Sci-Hub по десятибалльной шкале (8-10 балльные оценки). До начала пандемии COVID-19 $51,9 \%$ респондентов предпочитали получать статьи через свои библиотеки (48,1\% - через Sci-Hub), а во время пандемии это соотношение изменилось в поль- зу Sci-Hub (164 респондента или 77,3\% сильно зависели от Sci-Hub для доступа к платным ресурсам).

В заключение нашего обзора отметим, что отбираемые через Sci-Hub статьи цитируются в 2,21 раз более часто, чем отбираемые не через этот ресурс [15]. Настоящий обзор, включая все статьи, идентифицируемые через Google Scholar, показал, что какие-либо исследования по загрузке пиратских статей на сайте Sci-Hub российскими исследователями отсутствуют. Далее мы постараемся восполнить этот пробел.

\section{МАТЕРИАЛЫ И МЕТОДЫ ИССЛЕДОВАНИЯ}

Данные работы [1] представляют собой 6 файлов с расширением «*.tab», каждый из них отражает запросы пользователей за определенный период.

Файлы содержат:

- $\quad$ дату и время запроса;

- идентификатор DOI, который включает код издательства и код конкретной статьи в журнале, формируемый издательством;

- IP-адрес пользователя;

- название страны;

- название города;

- $\quad$ географические координаты - широту и долготу.

Вместе с данными 6-ти файлов был отобран файл статей в формате «*.csv», который содержит:

- название издательства;

- префикс издательства;

- дату последнего сохранения;

- дату последнего запроса.

Для получения результатов были отобраны запросы только с российских IP-адресов. С применением среды разработки РуCharm и языка программирования Python были обработаны исходные файлы и получены результаты по отбору статей российскими исследователями.

При обработке исходного файла статей выяснилось: если выделить названия издательств по префиксу, то количество отобранных статей составит 1780 431, что не соответствует количеству отобранных статей по городам России, равному 1521434. Причиной расхождения являются дублированные строки с информацией по издательству в исходном файле. Когда обрабатывается файл с исходными данными по количеству загруженных статей и находятся названия изданий по префиксам, то используется объединение двух дат фреймов, аналогично join в SQL. Taким образом, дублированные строки тоже учитываются и отсюда получается лишнее количество статей. После удаления дублирования, количество статей с российскими IP-адресами составило 1521434.

При обработке данных также было замечено, что общее количество отобранных статей по стране не равно общему количеству отбора по городам. Причина заключается в исходных файлах: в некоторых строках с данными отсутствует название города, вместо него стоит «N/A». Количество строк с таким значением было подсчитано и оно равнялось 29 264. Таким образом в дальнейшем анализировались 1492170 строк, что соответствует значению отбора статей по России. 


\section{РЕЗУЛЬТАТЫ ИССЛЕДОВАНИЯ И ИХ ОБСУЖДЕНИЕ}

Приведем результаты обработки данных работы [1] по распределению отобранных статей по издательствам, городам и регионам России.

В табл. 1 показан ранжированный перечень издательств с количеством не менее 900 отобранных статей.

Данные табл. 1 были сопоставлены с аналогичными результатами по Украине, полученными Сергеем Назаровцем [9]. Для этого мы объединили данные по Springer-Verlag и Nature Publishing Group, суммарно получив 206153 статей и Wiley Blackwell (Blackwell Publishing) c Wiley Blackwell (John Wiley \& Sons) суммарно получив 120391 статью. Для пяти ведущих издательств с наибольшими количеством их статей, отобранных российскими исследователями, получим следующие превышения над отбором статей украинскими исследователями: Elsevier - 4,3; Springer Nature - 4,5; Wiley Blackwell - 4,2; American Chemical Society - 3,5; Institute of Electrical and Electronics Engineers $-6,0$. Перечень ведущих издательств, с которых загружались статьи, для исследователей обоих стран был приблизительно одинаков.

В процессе обработки данных было идентифицировано городов и населённых пунктов в количестве 521, при этом в последних 35 городах наблюдалось по одной загрузке за весь полугодовой период. Среди них тех, которые на слуху - Туапсе, Дербент, Моздок, Назрань и Пижма. В табл. 2 представлена информация по первым 100 городам.

Таблица 1

Распределение по издательствам статей, отобранных российскими исследователями с ресурса Sci-Hub статей

\begin{tabular}{|c|c|c|}
\hline $\begin{array}{ll}\text { № } \\
\text { II/III }\end{array}$ & Издательство & $\begin{array}{l}\text { Oтбор c } \\
\text { Sci-Hub }\end{array}$ \\
\hline 1 & Elsevier & 453245 \\
\hline 2 & Springer-Verlag & 147419 \\
\hline 3 & American Chemical Society & 141852 \\
\hline 4 & $\begin{array}{l}\text { Wiley Blackwell } \\
\text { (John Wiley \& Sons) }\end{array}$ & 87034 \\
\hline 5 & $\begin{array}{l}\text { Institute of Electrical } \\
\text { and Electronics Engineers }\end{array}$ & 83948 \\
\hline 6 & Nature Publishing Group & 58734 \\
\hline 7 & The Royal Society of Chemistry & 48529 \\
\hline 8 & American Physical Society & 41296 \\
\hline 9 & Informa UK (Taylor \& Francis) & 35307 \\
\hline 10 & $\begin{array}{l}\text { Wiley Blackwell (Blackwell } \\
\text { Publishing) }\end{array}$ & 33357 \\
\hline 11 & American Institute of Physics & 29234 \\
\hline 12 & The Optical Society & 25691 \\
\hline 13 & JSTOR & 19636 \\
\hline 14 & IOP Publishing & 18863 \\
\hline 15 & Pleiades Publishing & 18742 \\
\hline 16 & $\begin{array}{l}\text { SPIE - International Society } \\
\text { for Optical Engineering }\end{array}$ & 15306 \\
\hline 17 & Oxford University Press & 14703 \\
\hline 18 & $\begin{array}{l}\text { American Association for the } \\
\text { Advancement of Science (AAAS) }\end{array}$ & 12045 \\
\hline 19 & SAGE Publications & 10890 \\
\hline 20 & $\begin{array}{l}\text { Springer (Kluwer Academic } \\
\text { Publishers) }\end{array}$ & 7442 \\
\hline 21 & Walter de Gruyter GmbH & 7210 \\
\hline 22 & Elsevier - Academic Press & 6974 \\
\hline 23 & Informa UK (Informa Healthcare) & 6284 \\
\hline 24 & Trans Tech Publications & 6256 \\
\hline 25 & $\begin{array}{l}\text { American Institute of Aeronautics } \\
\text { and Astronautics }\end{array}$ & 6190 \\
\hline 26 & Annual Reviews & 5373 \\
\hline
\end{tabular}

\begin{tabular}{|c|c|c|}
\hline $\begin{array}{l}\text { № } \\
\text { I/II }\end{array}$ & Издательство & $\begin{array}{l}\text { Отбор c } \\
\text { Sci-Hub }\end{array}$ \\
\hline 43 & S. Karger AG & 2847 \\
\hline 44 & Turpion & 2793 \\
\hline 45 & The Royal Society & 2496 \\
\hline 46 & $\begin{array}{l}\text { American Society for Biochemistry } \\
\text { and Molecular Biology }\end{array}$ & 2393 \\
\hline 47 & Elsevier - WB Saunders & 2336 \\
\hline 48 & $\begin{array}{l}\text { Ovid Technologies Wolters Kluwer- } \\
\text { American Heart Association }\end{array}$ & 2249 \\
\hline 49 & Brill Academic Publishers & 2159 \\
\hline 50 & New England Journal of Medicine & 2146 \\
\hline 51 & Informa UK (Ashley Publications) & 2029 \\
\hline 52 & American Vacuum Society & 2026 \\
\hline 53 & $\begin{array}{l}\text { Society for Industrial and Applied } \\
\text { Mathematics }\end{array}$ & 2010 \\
\hline 54 & Springer (Biomed Central Ltd.) & 1876 \\
\hline 55 & $\begin{array}{l}\text { Ovid Technologies (Wolters Kluwer) - } \\
\text { Lippincott Williams \& Wilkins }\end{array}$ & 1744 \\
\hline 56 & ASME International & 1674 \\
\hline 57 & Future Medicine & 1664 \\
\hline 58 & Bentham Science & 1635 \\
\hline 59 & Maney Publishing & 1631 \\
\hline 60 & Allerton Press & 1630 \\
\hline 61 & $\begin{array}{l}\text { Informa Healthcare } \\
\text { (Expert Reviews, LTD) }\end{array}$ & 1510 \\
\hline 62 & Cold Spring Harbor Laboratory Press & 1508 \\
\hline 63 & $\begin{array}{l}\text { American Association } \\
\text { for Cancer Research }\end{array}$ & 1451 \\
\hline 64 & The Endocrine Society & 1392 \\
\hline 65 & $\begin{array}{l}\text { Cambridge University Press } \\
\text { (Materials Research Society) }\end{array}$ & 1383 \\
\hline 66 & $\begin{array}{l}\text { Nature Publishing Group - } \\
\text { Macmillan Publishers }\end{array}$ & 1308 \\
\hline 67 & Springer - Adis & 1222 \\
\hline 68 & Emerald (MCB UP) & 1202 \\
\hline
\end{tabular}




\begin{tabular}{|c|l|c|}
\hline $\begin{array}{c}\text { № } \\
\text { n/I }\end{array}$ & \multicolumn{1}{|c|}{ Издательство } & $\begin{array}{c}\text { Отбор с } \\
\text { Sci-Hub }\end{array}$ \\
\hline 27 & $\begin{array}{l}\text { Proceedings of the National } \\
\text { Academy of Sciences }\end{array}$ & 5219 \\
\hline 28 & Mary Ann Liebert & 4914 \\
\hline 29 & World Scientific & 4475 \\
\hline 30 & The Electrochemical Society & 4342 \\
\hline 31 & Canadian Science Publishing & 4317 \\
\hline 32 & Thieme Publishing Group & 4161 \\
\hline 33 & $\begin{array}{l}\text { International Union of } \\
\text { Crystallography }\end{array}$ & 4131 \\
\hline 34 & BMJ & 3934 \\
\hline 35 & Japan Society of Applied Physics & 3680 \\
\hline 36 & Institution of Electrical Engineers & 3641 \\
\hline 37 & Cambridge University Press & 3612 \\
\hline 38 & $\begin{array}{l}\text { American Society for } \\
\text { Microbiology }\end{array}$ & 3566 \\
\hline 39 & $\begin{array}{l}\text { Association for Computing } \\
\text { Machinery }\end{array}$ & 3530 \\
\hline 40 & American Medical Association & 3237 \\
\hline 41 & American Geophysical Union & 3146 \\
\hline 42 & $\begin{array}{l}\text { Wiley Blackwell (Blackwell } \\
\text { Publishing) }\end{array}$ & 3011 \\
\hline
\end{tabular}

\begin{tabular}{|c|l|c|}
\hline $\begin{array}{c}\text { № } \\
\text { п/II }\end{array}$ & \multicolumn{1}{|c|}{ Издательство } & $\begin{array}{c}\text { Отбор с } \\
\text { Sci-Hub }\end{array}$ \\
\hline 69 & American Physiological Society & 1199 \\
\hline 70 & The University of Chicago Press & 1180 \\
\hline 71 & $\begin{array}{l}\text { American Association of Physics } \\
\text { Teachers }\end{array}$ & 1173 \\
\hline 72 & Acoustical Society of America & 1150 \\
\hline 73 & American Scientific Publishers & 1130 \\
\hline 74 & Oldenbourg Wissenschaftsverlag & 1125 \\
\hline 75 & CSIRO Publishing & 1121 \\
\hline 76 & American Society of Civil Engineers & 1104 \\
\hline 77 & Informa UK (Marcel Dekker) & 1093 \\
\hline 78 & Woodhead Publishing & 1088 \\
\hline 79 & $\begin{array}{l}\text { Ovid Technologies (Wolters Kluwer) } \\
\text { - American Academy of Neurology }\end{array}$ & 1077 \\
\hline 80 & Geological Society of London & 1048 \\
\hline 81 & Society for Neuroscience & 1022 \\
\hline 82 & $\begin{array}{l}\text { Muse - Johns Hopkins University } \\
\text { Press }\end{array}$ & 916 \\
\hline 83 & Springer-Verlag & 915 \\
\hline 84 & Geological Society of America & 908 \\
\hline
\end{tabular}

Таблииа 2

\section{Распределение отобранных пиратским образом статей российскими исследователями по ТОР-100 городам России}

\begin{tabular}{|c|c|c|c|c|c|c|c|}
\hline $\begin{array}{l}\text { № } \\
\text { п/III }\end{array}$ & Город & $\begin{array}{l}\text { Отбор с } \\
\text { Sci-Hub }\end{array}$ & $\begin{array}{c}\text { Код } \\
\text { региона }\end{array}$ & $\begin{array}{c}\text { № } \\
\text { п/ா/ }\end{array}$ & Город & $\begin{array}{l}\text { Отбор с } \\
\text { Sci-Hub }\end{array}$ & $\begin{array}{c}\text { Код } \\
\text { региона }\end{array}$ \\
\hline 1 & Москва & 731134 & 77 & 51 & Киров & 2214 & 43 \\
\hline 2 & Санкт-Петербург & 132623 & 78 & 52 & Владимир & 2174 & 33 \\
\hline 3 & Новосибирск & 57508 & 54 & 53 & Дубна & 2163 & 40 \\
\hline 4 & Казань & 55138 & 16 & 54 & Липецк & 2108 & 48 \\
\hline 5 & Томск & 26412 & 70 & 55 & Тюмень & 2050 & 72 \\
\hline 6 & Нижний Новгород & 25508 & 52 & 56 & Махачкала & 2012 & 5 \\
\hline 7 & Екатеринбург & 22024 & 66 & 57 & Одинцово & 1994 & 50 \\
\hline 8 & Королёв & 20589 & 50 & 58 & Саранск & 1967 & 13 \\
\hline 9 & Самара & 19401 & 63 & 59 & Подольск & 1935 & 50 \\
\hline 10 & Воронеж & 18962 & 36 & 60 & Чехов & 1924 & 50 \\
\hline 11 & Великий Новгород & 17723 & 53 & 61 & Курск & 1880 & 46 \\
\hline 12 & Иркутск & 16752 & 38 & 62 & Ульяновск & 1796 & 73 \\
\hline 13 & Саратов & 16678 & 64 & 63 & Люберцы & 1792 & 50 \\
\hline 14 & Ростов & 15260 & 76 & 64 & Ломоносов & 1740 & 78 \\
\hline 15 & Пермь & 14740 & 59 & 65 & Дмитров & 1723 & 50 \\
\hline 16 & Красноярск & 14576 & 24 & 66 & Тамбов & 1712 & 68 \\
\hline 17 & Челябинск & 13209 & 74 & 67 & Якутск & 1658 & 14 \\
\hline 18 & Иваново & 11643 & 37 & 68 & Брянск & 1634 & 32 \\
\hline 19 & Уфа & 10905 & 2 & 69 & Таганрог & 1472 & 61 \\
\hline 20 & Волгоград & 10798 & 34 & 70 & Йошкар-Ола & 1453 & 12 \\
\hline 21 & Краснодар & 10071 & 23 & 71 & Находка & 1354 & 25 \\
\hline 22 & Владивосток & 9794 & 25 & 72 & Апатиты & 1347 & 51 \\
\hline 23 & Сыктывкар & 9693 & 11 & 73 & Магнитогорск & 1344 & 74 \\
\hline 24 & Кемерово & 7200 & 42 & 74 & Ивановское* & 1270 & 50 \\
\hline 25 & Ярославль & 7172 & 76 & 75 & Саров & 1264 & 52 \\
\hline 26 & Омск & 6934 & 55 & 76 & Октябрьский & 1214 & 2 \\
\hline 27 & Солнечное & 6776 & 50 & 77 & Новочебоксарск & 1169 & 21 \\
\hline 28 & Белгород & 6070 & 31 & 78 & Столбовая** & 1125 & 50 \\
\hline 29 & Черноголовка & 6034 & 50 & 79 & Орёл & 1102 & 57 \\
\hline
\end{tabular}




\begin{tabular}{|c|l|c|c|}
\hline $\begin{array}{c}\text { № } \\
\text { п/I }\end{array}$ & \multicolumn{1}{|c|}{ Город } & $\begin{array}{c}\text { Отбор с } \\
\text { Sci-Hub }\end{array}$ & $\begin{array}{c}\text { Код } \\
\text { региона }\end{array}$ \\
\hline 30 & Калининград & 5964 & 39 \\
\hline 31 & Ставрополь & 4795 & 26 \\
\hline 32 & Обнинск & 4314 & 40 \\
\hline 33 & Ижевск & 4205 & 18 \\
\hline 34 & Петергоф & 3457 & 78 \\
\hline 35 & Астрахань & 3384 & 30 \\
\hline 36 & Пушкино & 3125 & 50 \\
\hline 37 & Фрязино & 3040 & 50 \\
\hline 38 & Гатчина & 2935 & 47 \\
\hline 39 & Калуга & 2892 & 40 \\
\hline 40 & Бердск & 2860 & 54 \\
\hline 41 & Рязань & 2837 & 62 \\
\hline 42 & Мытищи & 2732 & 50 \\
\hline 43 & Петрозаводск & 2695 & 10 \\
\hline 44 & Хабаровск & 2507 & 27 \\
\hline 45 & Тула & 2409 & 71 \\
\hline 46 & Жуковский & 2392 & 50 \\
\hline 47 & Тверь & 2365 & 69 \\
\hline 48 & Барнаул & 2351 & 22 \\
\hline 49 & Тольятти & 2293 & 63 \\
\hline 50 & Архангельск & 2230 & 29 \\
\hline
\end{tabular}

\begin{tabular}{|c|l|c|c|}
\hline $\begin{array}{c}\text { № } \\
\text { I/II }\end{array}$ & \multicolumn{1}{|c|}{ Город } & $\begin{array}{c}\text { Отбор c } \\
\text { Sci-Hub }\end{array}$ & $\begin{array}{c}\text { Код } \\
\text { региона }\end{array}$ \\
\hline 80 & Волобуево* & 1095 & 46 \\
\hline 81 & Волхонщино* & 1086 & 68 \\
\hline 82 & Чебоксары & 1069 & 21 \\
\hline 83 & Реутов & 1054 & 50 \\
\hline 84 & Чкаловск & 937 & 52 \\
\hline 85 & Кубань* & 906 & 23 \\
\hline 86 & Видное & 878 & 50 \\
\hline 87 & Пенза & 877 & 58 \\
\hline 88 & Снежинск & 839 & 74 \\
\hline 89 & Протвино & 819 & 50 \\
\hline 90 & Красногорск & 781 & 50 \\
\hline 91 & Кировск & 779 & 51 \\
\hline 92 & Сергиев Посад & 772 & 50 \\
\hline 93 & Сургут & 764 & 86 \\
\hline 94 & Смоленск & 761 & 67 \\
\hline 95 & Владикавказ & 745 & 15 \\
\hline 96 & Лобня & 744 & 50 \\
\hline 97 & Балашиха & 717 & 50 \\
\hline 98 & Дзержинский & 714 & 50 \\
\hline 99 & Домодедово & 706 & 50 \\
\hline 100 & Лыткарино & 681 & 50 \\
\hline
\end{tabular}

*- село, **-поселок

Таблиия 3

\section{Распределение отобранных пиратским образом статей российскими исследователями по регионам России}

\begin{tabular}{|c|c|c|c|c|c|c|c|}
\hline Регион & $\begin{array}{c}\text { Городское } \\
\text { население } \\
\text { в } 2016 \text { г. }\end{array}$ & $\begin{array}{l}\text { Oтбор c } \\
\text { Sci-Hub }\end{array}$ & $\begin{array}{c}\text { Отбор } \\
\text { в расчёте } \\
\text { на одного } \\
\text { жителя } \\
\end{array}$ & Регион & $\begin{array}{c}\text { Городское } \\
\text { население } \\
\text { в } 2016 \text { г. }\end{array}$ & $\begin{array}{l}\text { Отбор c } \\
\text { Sci-Hub }\end{array}$ & $\begin{array}{c}\text { Отбор } \\
\text { в расчёте } \\
\text { на одного } \\
\text { жителя }\end{array}$ \\
\hline Город Москва & 12232428 & 731555 & 0,0598 & Тверская область & 980532 & 2638 & 0,0027 \\
\hline $\begin{array}{l}\text { Город } \\
\text { Санкт-Петербург }\end{array}$ & 5282000 & 138327 & 0,0262 & $\begin{array}{l}\text { Тюменская } \\
\text { область }\end{array}$ & 1220828 & 2586 & 0,0021 \\
\hline $\begin{array}{l}\text { Московская } \\
\text { область }\end{array}$ & 6064591 & 75039 & 0,0124 & $\begin{array}{l}\text { Хабаровский } \\
\text { край }\end{array}$ & 1094393 & 2569 & 0,0023 \\
\hline $\begin{array}{l}\text { Новосибирская } \\
\text { область }\end{array}$ & 2193420 & 60712 & 0,0277 & $\begin{array}{l}\text { Костромская } \\
\text { область }\end{array}$ & 465912 & 2466 & 0,0053 \\
\hline $\begin{array}{l}\text { Республика } \\
\text { Татарстан }\end{array}$ & 2975910 & 56050 & 0,0188 & $\begin{array}{l}\text { Кировская } \\
\text { область }\end{array}$ & 985796 & 2337 & 0,0024 \\
\hline $\begin{array}{l}\text { Нижегородская } \\
\text { область }\end{array}$ & 2582160 & 28128 & 0,0109 & Алтайский край & 43834 & 2384 & 0,0544 \\
\hline Томская область & 780117 & 26862 & 0,0344 & $\begin{array}{l}\text { Чувашская } \\
\text { Республика } \\
\end{array}$ & 766320 & 2238 & 0,0029 \\
\hline $\begin{array}{l}\text { Свердловская } \\
\text { область }\end{array}$ & 3662334 & 23306 & 0,0064 & $\begin{array}{l}\text { Липецкая } \\
\text { область }\end{array}$ & 742152 & 2116 & 0,0029 \\
\hline Самарская область & 2565603 & 21791 & 0,0085 & $\begin{array}{l}\text { Республика } \\
\text { Дагестан }\end{array}$ & 1371942 & 2103 & 0,0015 \\
\hline $\begin{array}{l}\text { Воронежская } \\
\text { область }\end{array}$ & 1487395 & 19327 & 0,0130 & $\begin{array}{l}\text { Республика } \\
\text { Мордовия }\end{array}$ & 505000 & 2031 & 0,0040 \\
\hline $\begin{array}{l}\text { Новгородская } \\
\text { область }\end{array}$ & 434004 & 17723 & 0,0408 & $\begin{array}{l}\text { Ульяновская } \\
\text { область }\end{array}$ & 939750 & 1822 & 0,0019 \\
\hline Иркутская область & 1900701 & 17464 & 0,0092 & $\begin{array}{l}\text { Республика Саха } \\
\text { (Якутия) }\end{array}$ & 630765 & 1687 & 0,0027 \\
\hline Ростовская область & 4231000 & 17383 & 0,0041 & Брянская область & 855921 & 1651 & 0,0019 \\
\hline $\begin{array}{l}\text { Саратовская } \\
\text { область }\end{array}$ & 1871645 & 17249 & 0,0092 & $\begin{array}{l}\text { Республика } \\
\text { Марий Эл }\end{array}$ & 450730 & 1460 & 0,0032 \\
\hline $\begin{array}{l}\text { Челябинская } \\
\text { область }\end{array}$ & 2892652 & 16372 & 0,0057 & $\begin{array}{l}\text { Орловская } \\
\text { область }\end{array}$ & 503585 & 1105 & 0,0022 \\
\hline $\begin{array}{l}\text { Красноярский } \\
\text { край }\end{array}$ & 2374750 & 15423 & 0,0065 & $\begin{array}{l}\text { Пензенская } \\
\text { область }\end{array}$ & 916586 & 950 & 0,0010 \\
\hline
\end{tabular}




\begin{tabular}{|c|c|c|c|c|c|c|c|}
\hline Регион & $\begin{array}{c}\text { Городское } \\
\text { население } \\
\text { в } 2016 \text { г. }\end{array}$ & $\begin{array}{l}\text { Отбор c } \\
\text { Sci-Hub }\end{array}$ & \begin{tabular}{|c|} 
Отбор \\
в расчёте \\
на одного \\
жителя \\
\end{tabular} & Регион & $\begin{array}{c}\text { Городское } \\
\text { население } \\
\text { в } 2016 \text { г. }\end{array}$ & $\begin{array}{l}\text { Отбор с } \\
\text { Sci-Hub }\end{array}$ & $\begin{array}{c}\text { Отбор } \\
\text { в расчёте } \\
\text { на одного } \\
\text { жителя }\end{array}$ \\
\hline Пермский край & 1992424 & 15066 & 0,0076 & $\begin{array}{l}\text { Смоленская } \\
\text { область }\end{array}$ & 687113 & 877 & 0,0013 \\
\hline $\begin{array}{l}\text { Республика } \\
\text { Башкортостан }\end{array}$ & 2517473 & 12526 & 0,0050 & $\begin{array}{l}\text { Ханты- } \\
\text { Мансийский } \\
\text { автономный округ }\end{array}$ & 1519258 & 876 & 0,0006 \\
\hline $\begin{array}{l}\text { Краснодарский } \\
\text { край }\end{array}$ & 3041766 & 12489 & 0,0041 & $\begin{array}{l}\text { Республика } \\
\text { Северная Осетия - } \\
\text { Алания }\end{array}$ & 451326 & 746 & 0,0017 \\
\hline Ивановская область & 832722 & 12296 & 0,0148 & $\begin{array}{l}\text { Вологодская } \\
\text { область }\end{array}$ & 854848 & 730 & 0,0009 \\
\hline Приморский край & 1482633 & 11621 & 0,0078 & $\begin{array}{l}\text { Оренбургская } \\
\text { область }\end{array}$ & 1194000 & 623 & 0,0005 \\
\hline $\begin{array}{l}\text { Волгоградская } \\
\text { область }\end{array}$ & 1946880 & 11338 & 0,0058 & $\begin{array}{l}\text { Амурская } \\
\text { область }\end{array}$ & 539746 & 473 & 0,0009 \\
\hline Калужская область & 770640 & 10525 & 0,0137 & $\begin{array}{l}\text { Чукотский } \\
\text { автономный округ }\end{array}$ & 35000 & 468 & 0,0134 \\
\hline $\begin{array}{l}\text { Республика } \\
\text { Коми }\end{array}$ & 663000 & 10216 & 0,0154 & $\begin{array}{l}\text { Республика } \\
\text { Хакасия } \\
\end{array}$ & 371067 & 433 & 0,0012 \\
\hline $\begin{array}{l}\text { Кемеровская } \\
\text { область }\end{array}$ & 2324322 & 7585 & 0,0033 & $\begin{array}{l}\text { Камчатский } \\
\text { край }\end{array}$ & 245700 & 430 & 0,0018 \\
\hline $\begin{array}{l}\text { Ярославская } \\
\text { область }\end{array}$ & 1038407 & 7531 & 0,0073 & $\begin{array}{l}\text { Курганская } \\
\text { область }\end{array}$ & 527772 & 425 & 0,0008 \\
\hline Омская область & 1432398 & 7084 & 0,0049 & $\begin{array}{l}\text { Костромская } \\
\text { область }\end{array}$ & 465912 & 338 & 0,0007 \\
\hline $\begin{array}{l}\text { Белгородская } \\
\text { область }\end{array}$ & 1045169 & 6853 & 0,0066 & $\begin{array}{l}\text { Республика } \\
\text { Башкортостан }\end{array}$ & 2517473 & 304 & 0,0001 \\
\hline $\begin{array}{l}\text { Калининградская } \\
\text { область }\end{array}$ & 767108 & 6029 & 0,0079 & $\begin{array}{l}\text { Забайкальский } \\
\text { край }\end{array}$ & 733720 & 267 & 0,0004 \\
\hline $\begin{array}{l}\text { Ставропольский } \\
\text { край }\end{array}$ & 1637536 & 5400 & 0,0033 & $\begin{array}{l}\text { Кабардино- } \\
\text { Балкарская } \\
\text { Республика }\end{array}$ & 452052 & 232 & 0,0005 \\
\hline $\begin{array}{l}\text { Ленинградская } \\
\text { область }\end{array}$ & 1154048 & 4803 & 0,0042 & $\begin{array}{l}\text { Республика } \\
\text { Адыгея }\end{array}$ & 214742 & 189 & 0,0009 \\
\hline $\begin{array}{l}\text { Удмуртская } \\
\text { Республика }\end{array}$ & 996669 & 4219 & 0,0042 & $\begin{array}{l}\text { Карачаево- } \\
\text { Черкесская } \\
\text { Республика }\end{array}$ & 198982 & 144 & 0,0007 \\
\hline $\begin{array}{l}\text { Астраханская } \\
\text { область }\end{array}$ & 677635 & 3393 & 0,0050 & $\begin{array}{l}\text { Псковская } \\
\text { область }\end{array}$ & 453894 & 116 & 0,0003 \\
\hline $\begin{array}{l}\text { Мурманская } \\
\text { область }\end{array}$ & 699468 & 3076 & 0,0044 & $\begin{array}{l}\text { Республика } \\
\text { Тыва }\end{array}$ & 172356 & 73 & 0,0004 \\
\hline Курская область & 760271 & 3014 & 0,0040 & $\begin{array}{l}\text { Республика } \\
\text { Калмыкия }\end{array}$ & 125934 & 46 & 0,0004 \\
\hline $\begin{array}{l}\text { Владимирская } \\
\text { область }\end{array}$ & 1085590 & 2982 & 0,0027 & $\begin{array}{l}\text { Республика } \\
\text { Бурятия }\end{array}$ & 579576 & 32 & 0,0001 \\
\hline Тамбовская область & 629200 & 2906 & 0,0046 & $\begin{array}{l}\text { Магаданская } \\
\text { область }\end{array}$ & 139722 & 28 & 0,0002 \\
\hline Рязанская область & 808059 & 2858 & 0,0035 & $\begin{array}{l}\text { Сахалинская } \\
\text { область }\end{array}$ & 398366 & 22 & 0,00006 \\
\hline Республика Карелия & 424479 & 2849 & 0,0067 & $\begin{array}{l}\text { Ямало-Ненецкий } \\
\text { автономный } \\
\text { округ }\end{array}$ & 448632 & 13 & 0,00003 \\
\hline Тульская область & 1121252 & 2730 & 0,0024 & $\begin{array}{l}\text { Республика } \\
\text { Ингушетия }\end{array}$ & 82044 & 1 & 0,00001 \\
\hline
\end{tabular}

Сравнивая данные табл. 2 с данными работы [9] можно увидеть, что Москва по отбору статей опережает Киев в 3,9 раза, хотя Киев имеет больше отобранных статей на душу населения по сравнению с Москвой (на тысячу человек 64 против 60). Первые го- рода в обеих странах опережают по загрузкам вторые города примерно в одно и то же число раз $(5,1-5,2)$.

Небольшое различие в отборе статей по Москве и Санкт-Петербургу как регионам (субъектам) Российской Федерации от отбора по ним как городам, свя- 
зано с тем, что в их регионы входят небольшие города, например, такие как Ломоносов и Петергоф для Санкт-Петербургского региона.

В сравнении с украинской ситуацией [9] третий по количеству пиратских отборов украинский регион Харьковская область [9] - уступает по этому показателю, за исключением первых двух российских городов, только Московской и Новосибирской областям, а также Республике Татарстан.

\section{ЗАКЛЮЧЕНИЕ}

На основе выделенного в работе [1] с ресурса SciHub большого массива - 28 млн статей, нами идентифицированы публикации, отобранные пиратским образом российскими исследователями. Эти публикации распределены по издательствам, а также городам и регионам России. Их первые тройки выглядели так: Elsevier, Springer - Verlag, American Chemical Society; Москва, Санкт-Петербург, Новосибирск; Москва, Санкт-Петербург как субъекты РФ, Московская область.

Мы планируем продолжить обработку данных, определив распределение отобранных статей по областям научных исследований, а также по журналам. Было бы актуально, на наш взгляд, провести отбор данных из Sci-Hub в настоящее время, например, с 1 сентября 2021 по 29 февраля 2022 гг., чтобы получить ровно шестилетний интервал времени относительно предыдущих отборов. Тогда будет понимание, в какой научной информации нуждаются российские исследователи.

Теперь несколько общих мыслей относительно рассматриваемого нами явления и его связи с движением открытого доступа. В работе [12] делается вывод, что несмотря на рост Open Access, нелегальный доступ к научным статьям становится всё более распространенным. Если за полугодовой, выше рассмотренный, период ученые Мадрида, Барселоны и Валенсии отобрали, соответственно, 98143, 78535 и 26634 статей, то за весь 2017 г. они отобрали уже 868322,488101 и 215690 статей [16]. Таким образом, в пересчете на годовой период рост пиратских отборов в этих городах только через год произошел в 4,4; 3,1 и 8,1 раза. И так по всему миру. Энтузиасты движения Open Access тяжело шли к своей цели, а через 11 - 12 лет после запуска этого движения один единственный, но еще больший, энтузиаст моментально открыл практически стопроцентный доступ к научным публикациям. Этот доступ можно назвать Black Open Access Revolution. Молодая студентка коммунистических взглядов поставила на колени всех коммерческих издателей и застала врасплох правительственных чиновников по всему миру. Никакие их иски, никакие правительственные запреты здесь не в силе. Издатели пока не почувствовали никаких убытков, так как получают нелегальный контент те, кто мог получить его и легально, а также ученые из слаборазвитых стран, научные организации которых не имеют денег на доступ к их контенту. Но они его скоро почувствуют, когда научные библиотеки начнут отказываться от подписок, которые станут ненужными. Это сослужит хорошую службу движению легального Open Access, так как ускорит процесс перехода коммерческих издателей подписных журналов на модель открытого доступа, иначе они будут банкротами. Когда это произойдет, тогда пиратский проект Sci-Hub сам по себе отомрёт, о чём писала сама Александра Элбакян.

\section{СПИСОК ЛИТЕРАТУРЫ}

1. Bohannon J., Elbakyan A. Data from: Who's downloading pirated papers? // Everyone. Dryad Digital Repository. - 2016. - URL: https://doi.org/ 10.5061/dryad.q447c.

2. Travis J. In Survey, Most Give Thumbs - up to Pirated Papers // Science. - 2016. DOI: 10.1126/ science.aaf5704.

3. Oxenham S. Meet the robin good of science // Big Think. 9 February 2016. - URL: bigthink.com/ neurobonkers/a-pirate-bay-for science.

4. Parkill M. Sci-Hub: The academic cat is out the bag // Plum Analytics. - 2016. - 16 May.

5. Babutsidze Z. Pirated economics // MPRA. 2016. - paper 7/703.

6. Cabanac G. Bibliogifts in LibGen? Study of a text sharing platform driven by biblioleaks and crowdsourcing // Journal of the Association for Information Science and Technology. - 2016. - Vol. 67, №4. P. $874-875$.

7. Gardner C.C., Gardner G.J. Fast and furious (at publishers): the motivations behind crowdsourced research sharing // College \& Research Library. 2017. - January. - P. 1-24.

8. Himmelstein D.S., Romero A.R., McLaughlin S.R., Greshake B., Greene C.S. Sci-Hub Provides Access to Nearly All Scholarly Literature // Peer J. Preprints. - 2017. - Vol.5. - e3100v2. URL: https://doi.org/10.7287/peerj.preprints.3100v1.

9. Nazarovets S.A. Black Open Access in Ukraine: Analysis of Downloading Sci-Hub Publications by Ukrainian Internet Users // arXiv 1804.08479v1. URL: https://arxiv.org/abs/1804.08479v1 .

10. Timus N., Babutsidze Z. Pirating European Studies // Journal of Contemporary European Research. - 2016. - Vol.12, №3. - P. 783-91.

11. Androćec D. Analysis of Sci-Hub downloads computer science papers // Acta Univ. Sapientalae, Informatica. - 2017. - Vol. 9, №1. - P. 93-96.

12. Greshake B. Loking into Pandora's Box: The Content of Sci-Hub and its Usage // PMC. - 2017. URL: https://doi.org/10.12688/f1000research.11366.1.

13. Nicholas D. Sci-Hub: The new and ultimate disruptor? View from the front // Learned Publishing. 2018. - Vol.32, №2. - P.147 - 153. - URL: https://doi.org/10.1002/leap.1206.

14. Sahoo A., Shirpurkar A. The Sci-Hub Case: Why It is Time to Stop Favouring the Doctrinal Approach to Law over an Empirical One // SpicyIp. 2021. - 4 Jan. - URL: https://spicyip.com/2021/01/ the-sci-hub-case-why-it-is-time-to-stop-favouringthe-doctrinal-approach-to-law-over-an-empiricalone.html

15. Correa J.C., Laverde-Rojas H., MarmolejoRamos F., Tejada J., Bahnik Š. The Sci-Hub Effect: Sci-Hub doenloads lead to more article cita- 
tions // arXiv:2006.14979v2[cs.Dl] 29 Jan 2020. URL: https://arxiv.org/abs/2006.14979

16. González - Solar L., Fernández - Marcial V. SciHub, a challenge for academic and research libraries // El professional de la información. - 2019. - Vol. 28, №1. - e280112. - URL: 2 https://doi.org/10.3145/ epi.2019.ene 1.

Материал поступил в редакичию 21.04.21.

\section{Сведения об авторах}

МОСКОВКИН Владимир Михайлович - доктор географических наук, директор Центра развития публикационной активности, профессор кафедры мировой экономики Белгородского государственного национального исследовательского университета e-mail: moskovkin@bsu.edu.ru

ГАХОВА Нина Николаевна - кандидат технических наук, доцент, доцент кафедры прикладной информатики и информационных технологий Белгородского государственного национального исследовательского университета

e-mail: gahova@bsu.edu.ru

НАБОКОВ Алексей Юрьевич - магистрант кафедры прикладной информатики и информационных технологий Белгородского государственного национального исследовательского университета e-mail: 1272253@bsu.edu.ru 